\title{
SKRB ZA SVOJU RANJIVOST I OTPORNOST U VRIJEME PANDEMIJE COVID-A 19
}

\author{
Sanda Smoljo-Dobrovoljski
}

Sveučilište u Zagrebu

Katolički bogoslovni fakultet

sanda.smoljo@hotmail.com
UDK: 27-468:616-036.21Covid 19

https://doi.org/10.34075/cs.56.3.6

Prethodno priopćenje

Rad zaprimljen 6/2021

\section{Sažetak}

Pandemija COVID-a 19 značajno utječe na čovjekovo fizičko, psihičko i duhouno zdravlje, a posljedice pandemije manifestirat će se dugo vremena i nakon njezina završetka. Prevelik je naglasak na fizičko zdravlje, fizičku i socijalnu distancu, no pandemija je biološki opasna ne samo za tjelesno zdravlje već i za psihičko i duhovno. U pandemiji čovjek posebno osjeća svoju ranjivost na sve tri razine: fizičkoj, psihološkoj i duhounoj. Ovisno o tome kako čovjek doživljava svoju ranjivost, kako je integrira te koje obrambene kapacitete koristi u suočavanju sa stresnim situacijama, ovisit će i stanje njegova zdravlja.

Polazeći od kršćanske antropologije, surha radaje istražiti i analizirati kako se čovjek skrbi o vlastitoj ranjivosti i otpornosti te identificirati izvore ranjivosti u okviru psihološke i duhovne dimenzije. Nakon analize mentalnog stanja u doba pandemije u radu se obrađuju $i$ konkretni koraci kako integrirati vlastitu ranjivost te na koji način jačati psihološki i duhouni imunitet.

Ključne riječi: pandemija COVID-a 19, stres, ranjivost, otpornost, integracija

\section{UvoD}

Otvoriti pitanje skrbi za ranjivost i otpornost u vrijeme COVID-a 19 spada u prioritete svih institucija koje se bave izobrazbom, odgojem, psihološkom, duhovnom i pastoralnom pratnjom. Aktualnost ove teme neće nestati popuštanjem epidemijskih mjera, niti cijepljenjem velikog broja stanovništva. Naprotiv, zbog psihosocijalnih posljedica COVID-a 19 na svjetskoj razini u vidu masovne histeri- 
je, ekonomskih i financijskih gubitaka, ${ }^{1}$ itekako je važno raditi na programima i strategijama prevencije, edukacije, liječenja psihosocijalnih i mentalnih poremećaja. Ovo je posebno važno na globalnoj razini, jer, uz COVID-19, pandemija koja je u progresu u 21. stoljeću je pandemija mentalnih poremećaja. ${ }^{2}$ Do sada je objavljen niz znanstvenih i stručnih radova, kliničkih istraživanja ${ }^{3}$ na svjetskoj razni koja donose podatke o prevalenciji poremećaja, mogućim ishodima i utjecaju COVID-a 19 na mentalno zdravlje. Stoga bi zdravstveni i odgojni sustavi uvažavajući statističke i kliničke podatke trebali promptno reagirati i pripremati programe u svrhu zaštite i prevencije, a ne samo voditi dijagnostički i kurativni dio.

Prvi cilj ovoga rada je istražiti i analizirati kako se čovjek skrbi o vlastitoj ranjivosti i otpornosti, posebno u vrijeme postmoderne, u kojem dominira kult i estetika tijela, a nutrina nerijetko ostaje zapuštena, zanemarena. Pojava raznih pandemija i fobija - pandemija mentalnih poremećaja, fenomen koronafobije - masovni strah od COVID-a $19,{ }^{4}$ samo su neki od signifikantnih znakova koje bi trebalo imperativno čitati kao poziv za povratak sebi i jačanje intrapsihičkih i interpersonalnih kapaciteta.

Drugi cilj rada je ići dalje od same analize i dijagnostike mentalnog stanja u vrijeme COVID--a 19 te istražiti izvore ranjivosti iz psihološke i duhovne dimenzije kako bi se ukazao put kojim bi trebalo krenuti u cilju prihvaćanja i integriranja vlastite ranjivosti te jačanja psihološke i duhovne otpornosti. Rad je podijeljen $\mathrm{u} 4$ dijela: u prvom dijelu analizira se stanje $\mathrm{u}$ vrijeme pandemije koronavirusa, u drugom dijelu istražuje se dinamika ranjivosti iz psihološko-duhovne dimenzije, treći dio bavi se pitanjem otpornosti, a u završnom dijelu daju se smjernice za jačanje psihološke i duhovne otpornosti.

1 Usp. Souvik Dubey - Payel Biswas - Ritwik Ghosh, Psychosocial impact of COVID-19, Diabetes \& Metabolic Syndrome: Clinical Research \& Reviews 14 (2020.), 779-788., https://doi:10.1016/j.dsx.2020.05.035 (12. 5. 2021.)

2 Usp. Veronica Tucci - Nidal Moukaddam, We are the hollow men: The worldwide epidemic of mental illness, psychiatric and behavioral emergencies, and its impact on patients and providers, Journal of Emergencies Trauma, Shock .10 (2017.) 4-6, https://doi: 10.4103/0974-2700.199517 (20. 4. 2021.).

3 Usp. Ravi Philip Rajkumar, COVID-19 and mental health: A review of the existing literature. Asian Journal of Psychiatry 52 (2020.), https://doi:10.1016/j. ajp.2020.102066 (20. 4. 2021.).

4 Usp. Gordon J.G. Asmundson - Steven Taylor, Coronaphobia: fear and the 2019-nCoV outbreak. Journal of Anxiety Disorders 70 (2020.), https://doi.org/ 10.1016/j.janxdis.2020.102196 (15. 5. 2021.). 


\section{Analiza mentalnog stanja u VRIJEME PANDEMiJe KORONAVIRUSA}

\subsection{Kako mentalizirati u doba korone?}

Situacija u kojoj se nalazi cijeli svijet zbog pojave globalne zarazne epidemije izazvane novim koronavirusom je novo iskustvo puno izazova za cijelo čovječanstvo, koje traje duže nego što je obični čovjek očekivao. Pojava pandemije dovela je do promjena kod mnogih osoba kako u profesionalnom tako i u osobnom životu. ${ }^{5} \mathrm{U}$ cilju sprječavanja širenja virusa i bolesti COVID-19 te zaštite zdravlja uvedene su izvanredne preventivne mjere, koje su utjecale na sve četiri dimenzije čovjekova života: tjelesnu, psihološku, socijalnu i duhovnu.

Iako su profilaktičke mjere isključivo usmjerene na obuzdavanje širenja zaraznog virusa, odnosno na izolaciju, socijalnu distancu, ograničenje kretanja, sve se češće nameću pitanja koja se tiču mentalnog zdravlja: Hoće li zbog psihoze koja se stvorila više stradati psihičko nego tjelesno zdravlje? Koliko je svakodnevno čovjekovo mentaliziranje ${ }^{6}$ opterećeno situacijom koronavirusom čiji se učinci reflektiraju na sve pore čovjekova života“? Klinička iskustva upućuju da će novi, nepoznati izazovi s kojima ćemo se susretati i nakon popuštanja mjera, utjecati na mentalne procese. Fizička i socijalna distanca, ${ }^{7}$ nemogućnost spontanih susreta, psihološka opterećenost zbog neizvjesnosti i straha, imaju svoje reperkusije na mentalni život ${ }^{8}$ čovjeka, kod kojeg se mogu razviti razni oblici psiho-

5 Usp. Kang-Hyun Park - Ah-Ram Kim - Yang Min-Ah et al., Impact of the COVID19 pandemic on the lifestyle, mental health, and quality of life of adults in South Korea, PLOS ONE 16 (2021.) 2, https://doi.org/10.1371/journal.pone.0247970. (3. 11. 2021.).

6 Usp. Vlatka Boričević Maršanić - Ljiljana Karapetrić Bolfan - Gordana Buljan Flander et al., „Vidjeti sebe izvana, a druge iznutra“ - Mentalitacija u djece i adolescenata i tretman temeljen na mentalizaciji za adolescente, Socijalna psihijatrija 45 (2017.) 1, 43-56.

7 Usp. Ruta Clair - Maya Gordon - Matthew Kroon et al., The effects of social isolation on well-being and life satisfaction during pandemic, Humanities and Social Sciences Communications 8 (2021.) 28, https://doi.org/10.1057/s41599-02100710-3, (28. 5. 2021.).

8 Usp. Betty Pfefferbaum - Carol S. North, Mental health and the Covid-19 pandemic, New England Journal of Medicine, 383 (2020.) 510-512; Jonathan P. Rogers - Edward Chesney - Dominic Oliver et al., Psychiatric and neuropsychiatric presentations associated with severe coronavirus infections: A systematic review and meta-analysis with comparison to the Covid-19 pandemic, The Lancet Psychiatry 7 (2020.) 7, 611-627. https://doi: 10.1016/S2215-0366(20)30203-0, (28. 5. 2021.). 
loških nestabilnosti i psihopatologija. ${ }^{9}$ Prema istraživanjima djeca i adolescenti spadaju u posebno ranjivu populaciju, ${ }^{10}$ a podaci ukazuju da je zbog socijalne isključenosti značajan porast zlostavljanja, zanemarivanja djece te nasilja u obitelji. ${ }^{11} \mathrm{~S}$ druge pak strane, ranjiva populacija su i starije osobe. Kod njih se u vrijeme zatvaranja (lockdown) znatno češće javljala psihološka kriza s izraženim anksioznim simptomima. ${ }^{12}$

Na temelju podataka kliničkih studija na globalnoj razni, koji su prikupljeni od osoba koje pripadaju različitim dobnim skupina i profesijama, čini se da je mentaliziranje sebe i drugih za vrijeme trajanja globalne epidemije znatno obojeno, ali ne i determinirano, tjeskobno-depresivnom slikom.

\subsection{Pojava novih mentalnih oboljenja}

Osobe koje već boluju od mentalnih bolesti mogu imati značajno pogoršanje stanja ili se nova oboljenja mogu javiti kod osoba koje imaju slabiju psihološku strukturu ${ }^{13}$, odnosno ranjivije su i imaju slabo razvijene ili nezrele obrambene mehanizme. Kod značajnog broja stanovnika Republike Hrvatske i Bosne i Hercegovine novonastala situacija aktivirala je ratne psihotraume koje su, neprerađene, obrambenim mehanizmima potiskivanja i negacije gurnute u podsvijest. Kod takvih osoba koje nose zaleđena bolna sjećanja, novonastala situacija može biti okidač za pojavu posttraumatskog stresnog poremećaja (PTSP-a). Kod nekih osoba pojava zarazne epidemije već uzrokuje niz stresnih reakcija, ${ }^{14}$ kao što su nesanica, pojačana

9 Usp. Kanwar Hamza Shuja - Muhammad Aqeel - Abbas Jaffar et al., COVID19 pandemic and impending global mental health implications, Psychiatria Danubina 32 (2020.) 1, 32-35.

10 Usp. Shijo John Joseph - Samrat Singh Bhandari - Suman Ranjitkar et al., School closures and mental health concerns for children and adolescents during the Covid-19 pandemic, Psychiatria Danubina 32 (2020.) 2, 309-310.

11 Usp., Mia Roje Đapić - Gordana Buljan Flander - Krešimir Prijatelj, Children Behind Closed Doors Due to COVID-19 Isolation: Abuse, Neglect and Domestic Violence, Archives of Psychiatry Research 56 (2020.) 2, 181-192.

12 Usp. Abhinav Garg - Vikas Gaur - Deepak Salvi, The Impact of the COVID-19 Pandemic and Lockdown on Anxiety in the Elderly population: a cross sectional study, Archives of Psychiatry Research 57 (2021.), 139-146.

13 Usp. Nenad Jakšić - Lovorka Brajković - Ena Ivezić et al., The role of personality traits in posttraumatic stress disorder (PTSD), Psychiatria Danubina 24 (2012.) 3, 256-266.

14 Usp. Cindy Goh - Mark Agius, The stress-vulnerability model how does stress impact on mental illness at the level of the brain and what are the consequences? Psychiatria Danubina 22 (2010.) 2, 198-202. 
uznemirenost, osjećaj nesigurnosti, tjeskobe, socijalne anksioznosti, pojava psihosomatskih simptoma poput glavobolje, mučnine, znojenja, vrtoglavice, nedostatka energije, općih bolova i sl.

Sve to mogu biti reakcije na akutni stres, i on po sebi ne izaziva veću štetu jer je moguće nositi se s njim, kanalizirati ga i liječiti. No ako se radi o prolongiranom djelovanju stresogena, akutni stres može postati kronični, a on ima vrlo razarajuće posljedice na sve razine čovjekova života i uništava ga postupno. Stres ne narušava samo psihološku ravnotežu nego negativno utječe i na druge organe, uzrokujući razne metaboličke promjene u organizmu. ${ }^{15}$

Kronični stres razvija se kada se osoba osjeća bespomoćno i kada ne vidi izlaz iz teške situacije u kojoj se nalazi. Kronični stres utječe na sve aspekte života, postupno dovodi do tjelesnog i psihičkog propadanja, što iz dana u dan smanjuje funkcionalnost osobe. Neke se osobe naviknu na kronični stres, što je vrlo opasno. Ignorirati tjelesne i psihološke alarme često završava fatalnim ishodom kao što je moždani udar, srčani udar, karcinom, bolesti endokrinog sustava i druga oboljenja. ${ }^{16}$ Sve češća pojava nasilja u obiteljima za vrijeme izolacije i ograničenja kretanja posljedica je stresa, koji varira od akutne do kronične faze. S druge pak strane, pojava suicida, ${ }^{17} \mathrm{kao}$ oblika autoagresije, nerijetko ima u pozadini izloženost dugotrajnom stresu. Potres koji je u ožujku 2020. godine pogodio Zagreb i druge dijelove Hrvatske, uz COVID-19 dodatni je rizični čimbenik, koji može utjecati na postpandemijsku prevalenciju mentalnih poremećaja. ${ }^{18}$

\subsection{PTSP kao reakcija na COVID-19}

Kod PTSP-a ${ }^{19}$ radi se o intenzivnom psihotraumatskom iskustvu, koje dovodi do ugroženosti osobnog integriteta ili integriteta

15 Usp. Ibid, 200.

16 Usp. Joel E. Dimsdale, Psychological stress and cardiovascular disease, Journal of the American College of Cardiology 51 (2008.), 13, 1237-1246., https://doi. org/10.1016/j.jacc.2007.12.024 (2.11.2021.); Ranabir, Salam - K. Reetu, Stress and hormones, Indian journal of endocrinology and metabolism 15 (2011.) 1, 18-22., https://doi.org/10.4103/2230-8210.77573 (3. 11. 2021.).

17 Usp. Aurel Pera, Depressive Symptoms, Anxiety Disorder, and Suicide Risk During the COVID-19 Pandemic, Frontiers in Psychology (2020.), |https://doi. org/10.3389/fpsyg.2020.572699 (23. 4. 2021.).

18 Usp. Krešimir Ćosić - Siniša Popović - Marko Šarlija, Impact of human disasters and COVID-19 pandemic on mental health: potential of digital psychiatry, Psychiatria Danubina 32 (2020.) 1, 25-31.

19 Više o PTSP-u vidi: Monika Šerić - Marijana Braš - Veljko Đorđević, Posttraumatski stresni poremećaj i kronična bol - neurobiološka podloga biopsihosocijalnog odnosa, Socijalna psihijatrija 43 (2015.) 2, 67-72. 
bliskih osoba i najčešće je kraćeg trajanja. Kada se govori o utjecaju koronavirusa, radi se o dugotrajnom strahu nižeg intenziteta, neizvjesnosti, opasnosti, tako da je očekivano da će se pojavljivati veći broj anksiozno-depresivnih poremećaja i PTSP-a koji se javljaju kao reakcija na situacije koje su ostavile izuzetno jake psihotraumatične posljedice na osobu. ${ }^{20} \mathrm{Na}$ temelju prethodnih analiza okolnosti kojima je obuhvaćen velik broj osoba, postavlja se pitanje: Je li opravdano govoriti o PTSP-u prouzročenom koronavirusom? Ovdje je važno napraviti razliku između onih koji su izravno pogođeni zarazom i onih koje zaraza izravno ne pogađa. Studije pokazuju da u oba slučaja pandemija izaziva značajan stres na život u različitim dijelovima svijeta, s time da su najviše pogođena žarišna područja. ${ }^{21}$

Prema analizama procjenjuje se da bi COVID-19 u budućnosti mogao kod mnogih osoba izazvati PTSP ${ }^{22}$ Kliničko iskustvo i studije pokazuju da velik broj otpuštenih bolesnika koji su bili u izolaciji u bolnicama pokazuje značajne simptome PTSP-a; kada se govori o mentalnom zdravlju medicinskih sestara i liječnika koji su radili na odjelima specijaliziranim za COVID-19, primjetan je značajan broj zdravstvenih djelatnika koji su razvili ozbiljne psihološke poteškoće, u vidu depresije, anksioznosti i nesanice. U rizične skupine koje bi mogle imati dugoročne psihološke probleme, poput stresa, anksioznosti, straha od bolesti, ili neki drugi oblik poremećaja (anksiozno-depresivni poremećaj, PTSP), spadaju osobe koje su pozitivne na COVID-19 te su zbog toga morale biti u izolaciji. Nadalje, osobe koje su izgubile svoje bližnje, potom osobe koje su iznenada izgubile posao mogu biti pod većim pritiskom od prosjeka, kao i oni koji već imaju neko mentalno oboljenje, poput anksioznosti ili depresije.

Kombinacija vanjskih čimbenika (dugotrajna izloženost stresu) i intrapsihička dinamika osobe - labilnija psihološka struktura, nizak prag tolerancije na stres i frustraciju, nedostatak emocionalne i socijalne potpore, deficit ili slaba razvijenost sublimatornih kanala

20 Usp. Qiu Jianyin - Shen Bin - Zhao Min et al., A nationwide survey of psychological distress among Chinese people in the COVID-19 epidemic: implications and policy recommendations, General Psychiatry 33 (2020.), https:// e100213. doi:10.1136/ gpsych-2020-100213 (25. 4. 2021.).

21 Usp. Nader Salari - Amin Hosseinian-Far - Jalali Rostam et al., Prevalence of stress, anxiety, depression among the general population during the COVID-19 pandemic: a systematic review and meta-analysis, Globalization and Health 16 (2020.) 57, https://doi.org/10.1186/s12992-020-00589-w (2. 11. 2021.).

22 Usp. Gabriele d'Ettorre - Giancarlo Ceccarelli - Letizia Santinelli et al., PostTraumatic Stress Symptoms in Healthcare Workers Dealing with the COVID-19 Pandemic: A Systematic Review, Int J Environ Res Public Health 18 (2021.) 2, 601. https:// doi: 10.3390/ijerph18020601 (22. 5. 2021.). 
(„ventili“ za kanaliziranje frustracije i neugodnih emocija) pogodno su tlo za razvoj psihičkih poteškoća u doba pandemije koronavirusa i u vrijeme postpandemije.

\section{DINAMIKA RANJIVOSTI IZ PSIHOLOŠKO-DUHOVNE PERSPEKTIVE}

\subsection{Ranjivi i ranjeni u pandemiji}

Iz prethodnih analiza i podataka recentnih svjetskih istraživanja proizlazi da se vrijeme pandemije COVID-a 19 može opisati kao vrijeme neočekivanog intenzivnog stresa zbog kojeg su na vrh ledenog brijega isplivale čovjekova ranjivost i psihološka (ne)otpornost. Prolongirana neizvjesnost, nedovoljno znanje o tijeku, mutacijama i posljedicama bolesti u kombinaciji s emocionalnim, socijalnim, duhovnim i ekonomskim ograničenjima utjecali su na čovjekovo doživljavanje sebe i okoline te percepciju da se živi u vremenu stabilne nestabilnosti. U tim okolnostima čovjek ima osjećaj gubitka kontrole, što ga čini posebno osjetljivim, a njegov psihološki odgovor na gubitak osjećaja kontrole može biti prilika za rast ili regresiju. Drugim riječima, bolna emocionalna iskustva mogu biti mjesta rasta i novog pristupa skrbi o sebi ili, suprotno, mjesto blokade i odustajanja od vlastitog života.

Ranjivost je inherentni dio ljudske egzistencije ${ }^{23}$ i kao takva može biti prihvaćena ili potisnuta. Ona nije točka slabosti, nego mjesto rasta i razvoja novog iskustva i odnosa sa sobom i drugim/Drugim. U suprotnom, negacija vlastite ranjivosti može voditi do gubljenja prilike za odnos i iskustvo koji donose svrhovitost, vitalnost i dinamiku života, a u nekim slučajevima i do viktimizma i manipulacije. Negacijom važnog, ranjivog dijela psihičkog života čovjek sebe udaljava od normalnog doživljavanja i funkcioniranja, zatvara se u infantilne, nezrele, a ponekad i patološke obrasce, koje potom opsesivno ponavlja kako bi se zaštitio od iskustva i prorade neugodnih, bolnih, emotivnih stanja. ${ }^{24}$

U vrijeme pandemije COVID-a 19 necenzuriran i nefiltriran pristup pojedinca društvenim mrežama ${ }^{25}$ te neselektivno praćenje progresivnog rasta broja oboljelih i preminulih također su negativ-

23 Usp. Martina Vuk, Razumijevanje ranjivosti kao sustavnoga i preciznog diskursa, Nova prisutnost 18 (2020.) 3, 577-592.

24 Usp. Sister Marie Beha, Emotional Healing, Human development 19 (1998.) 3, 31-36.

25 Usp. Daniel A. González-Padilla - Leonardo Tortolero-Blanco, Social media influence in the COVID-19 Pandemic, Int Braz J Urol 46 (2020.) 1, 120-124. https:// doi.org/10.1590/S1677-5538.IBJU.2020.S121 (26. 4. 2021.). 
no utjecali na već akumulirane neugodne i bolne emocije te su $\mathrm{u}$ nekim slučajevima bili okidač za aktiviranje psihopatoloških procesa. Izloženost ekstremnim stanjima, osjećaj ugroženosti i opasnosti neminovno suočava čovjeka s pitanjem smrti, koja uključuje pitanje patnje, boli, krivnje, oprosta i žalovanja. ${ }^{26}$ Poricanje postojanja virusa i bolesti, bijeg u virtualni svijet i razne toksične kompenzacije klasičan je oblik negiranja patnje, u konačnici smrti. Kao što je ranjivost sastavni dio ljudske naravi i potiče čovjeka da traži drugoga/Drugoga, tako i „patnja postoji jer samo preko patnje, upoznajući svoje granice i svoje nedostatke, [čovjek] dobiva poticaj da traži u Bogu pomoć, zaštitu i spasenje, sve one stvari koje sam sebi ne može niti će ikad moći dati“. ${ }^{27}$

U dramatičnim iskustvima pandemije $\mathrm{i}$ potresa biti ranjiv $\mathrm{i}$ ranjen normalna je i očekivana pojava, a ovisno o psihološkoj otpornosti, nutarnjim i vanjskim (ne)podržavajućim resursima netko sanira ranu i postane još jači, a netko može ostati trajno ranjen posljedicama pandemije i potresa na psihološkoj i duhovnoj razini.

\subsection{Psihogeneza ranjivosti}

Prema autorima Zubin i Spring ${ }^{28}$ ranjivost je rezultat djelovanja nekoliko čimbenika: genetike, okoline, učenja i socijalnih iskustava. Interakcija ovih čimbenika utječe na čovjekov stupanj osjetljivosti i prag tolerancije na stresne situacije. Osoba s niskim pragom tolerancije pod pritiskom stresora niskog intenziteta može razviti određene psihološke poteškoće i psihopatološke poremećaje. Osobe koje su otpornije mogu razviti neki psihološki problem ili neki oblik psihopatologije samo u situacijama kada su izložene katastrofama koje dugo traju. Biološka, psihološko-socijalna i duhovna dinamika koje su se razvijale od najranijih iskustava s primarnim skrbnicima utječu na formiranje zdrave ličnosti ili na razvoj poremećaja ličnosti. Kod osoba kod kojih postoji intrinzična fragilnost koja dolazi iz biološki naslijeđene strukture zbog poteškoća u funkcioniranju mozga uz pojavu psihosocijalnih stresova - životne krize, gubitak bliskih osoba, narušeni međuljudski odnosi, problemi na radnome mjestu

26 Usp. Dubravka Hercigonja-Kocijan, Psihološki aspekti umiranja i smrti, Crkva u svijetu 33 (1998.) 1, 21-29.

27 Marijan Vugdelija, Patnja i bol u sujetlu Biblije i ljudskog iskustva, Franjevačka visoka bogoslovija, Zagreb, 1976., 72.

28 Usp. Joseph Zubin - Bonnie Spring, Vulnerability: a new view of Schizophrenia, Journal of Abnormal Psychology 86 (1977.) 2, 103-126. https://doi.org/ 10.1037/0021-843X.86.2.103 (25. 4. 2021.). 
- može doći do pojave mentalnih oboljenja (npr. depresija, anksiozni poremećaji, PTSP). Genetska predispozicija nije dovoljna za razvoj mentalnih poremećaja, nego se zahtijeva i interakcija s bio-psihosocijalnim stresorima. ${ }^{29}$

Razumjeti psihogenezu ranjivosti zahtijeva povratak u prošlost, u obiteljsku dinamiku i obiteljske odnose. Mnogi stariji, ali i recentni revolucionarni psihoanalitičari, neopsihoanalitičari, humanistički i egzistencijalni psiholozi (Freud, Erikson, Rogers, Mahler, Winnicott, Bowlby, Maslow, Frankl, Kohut, Kernberg i drugi) u svojim djelima pokazali su važnost odnosa s primarnim figurama te kako psihološko rođenje, koje se javlja kao posljedica dobrog dijadnog, ${ }^{30}$ kasnije trijadnog odnosa (majka-dijete, majka-otac-dijete) utječe na razvoj pozitivne slike o sebi, psihološkog identiteta, u okviru kojeg će dijete razvijati empatiju prema sebi, prihvaćati vlastitu ranjivost, razvijati autonomiju te postavljati zdrave granice između sebe i drugih. Kako bi dijete moglo postići razvojno zahtjevne zadatke i prijeći razvojne prekretnice „dovoljno dobro“ od krucijalne važnosti su odgovori na dva pitanja: „tko me voli?“ i „vrijedim li?“. Iskustvo ljubavi i bezuvjetne prihvaćenosti od primarnih figura baza je za zdrav razvoj svih kasnijih odnosa: prijateljskih, romantičnih, kolegijalnih, odnosa s Bogom. Škola ranjivosti pohađa se vrlo rano, u majčinu i očevu krilu, u interakciji roditelji-dijete. U mjeri u kojoj majka i otac prihvaćaju svoju ranjivost, što ih predisponira da prihvaćaju i djetetovu, dijete uči prihvaćati sebe, otvarati sebe, izložiti se. Nadalje, uči da umjesto kritike, prosudbe, vikanja, dobije objašnjenje i strpljivo ga se bodri u izvršenju zadatka. U suprotnom, ako dijete kada se pokaže ranjivim, kada otvori svoje emocije, misli, pokaže svoje nezadovoljstvo i bijes, doživi odbacivanje, agresiju, sram, tugu, strah, onda se aktiviraju obrambeni mehanizmi psihe kako bi se zaštitilo. Drugim riječima, dijete uči stvarati maske, kako bi „kupilo“ malo ljubavi i bilo prihvaćeno ne zbog onoga što jest, nego zbog onoga što drugi očekuju da bude. Negirajući vlastitu ranjivost, uči se stvarati nutarnji jaz između onoga što dijete, kasnije odrasla osoba, osjeća i onoga što okolina očekuje. Kada se u obiteljskim odnosima spomenuta neugodna i negativna iskustva često ponavljaju, dijete, a kasnije odrastao čovjek, čini sve moguće kako ne bi ponovilo bolno iskustvo srama, poniženja, ugroženosti. Kod nekih osoba dola-

29 Usp. Cindy Goh - Mark Agius, The stress-vulnerability model how does stress impact on mental illness at the level of the brain and what are the consequences? Psychiatria Danubina 22 (2010.) 2, 198.

30 Usp. Mirela Vlastelica, Rani odnos majka-dijete u svjetlu neuroznanstvenih spoznaja, Medicinska naklada, Zagreb, 2014. 
zi do rascjepa emotivnog i intelektualnog, negacije, potiskivanja, sve kako bi se autentični dio, ranjivi dio, sakrio i kako bi osoba (p)ostala „neranjiva“. Što osoba više bježi od svoje ranjivosti, svoje otvorenosti, emocionalne izloženosti i rizika, sve se više otuđuje od sebe, drugih i postaje formalna, rigidna, usmjerena na pravila i norme. S druge pak strane, može biti nasilna u traženju posebne pažnje, divljenja, ekskluzivnih povlastica.

U vrijeme pandemije mnogi su izgubili prividne zaštite, materijalnu sigurnost, privilegije, ekskluzivna prava, kompenzacije raznih oblika, što je utjecalo i ubrzalo proces da na površinu isplivaju stari problemi, dugo potiskivane rane, neriješeni intrapsihički i interpersonalni konflikti. U tim situacijama do izražaja je došla ne samo ranjivost već i ranjenost čovjeka koja ima puno dublje korijene, a u vrijeme pandemije postala je vidljiva. Nedostatak zrelih mehanizama i slaba psihološka otpornost da se nosi s kriznim situacijama $u$ nekim obiteljima eskalirala je samoubojstvom i ubojstvom članova obitelji. ${ }^{31}$

\subsection{Dinamika starog Adama i novog Adama u vrijeme pandemije}

Polazeći od kršćanske antropologije, analizirat će se ranjivost kao ontološka datost kršćanina i kao prilika za rast i sazrijevanje. Kako kršćanin iščitava znakove vremena, služe li mu globalna događanja da prizna svoju ranjivost i otvori se Drugome ili se prepušta strahovima i sumnjama koji su obuzeli cijeli svijet te umjesto predanja i suradnje s Bogom zaboravlja ga i postaje tjeskobnog duha, tjeskobni vjernik? „Već od samog svog postanka čovjek je pozvan da stupi u dijalog s Bogom, jer samo stoga postoji što ga je Bog iz ljubavi stvorio i što ga iz ljubavi stalno uzdržava. Čovjek ne može punim životom po istini živjeti ako tu ljubav slobodno ne prizna i ako se svome Stvoritelju ne povjeri."32

Ali u srcu čovjeka prebivaju različite želje (emocionalno i razumski željeti), svijet potreba, emocija, želja i svijet ideala, vrijednosti. Psihičke predispozicije (potrebe, emocije, nagnuća, svijest i podsvijest) mogu sprječavati da Božja riječ padne na plodno tlo. Utjecaj nezrelih dinamika u psihi čovjeka može utjecati na to da se vjera živi kao tradicija, poziv, i poslanje obavlja kao posao, a riječ naviješta

31 Usp. Carlo Lazzari - Ahmed Shoka - Abdul Nusair et. al., Psychiatry in time of COVID-19 pandemic, Psychiatria Danubina 32 (2020.) 2, 229-235.

32 HRVATSKA BISKUPSKA KONFERENCIJA (ur.), Katekizam Katoličke Crkve, Zagreb, 1994., br. 27. 
bez žara. ${ }^{33}$ Čovjekov život praćen je konstantnom osnovnom dijalektikom, koja je sastavni dio njegova života. Drugim riječima, čovjek je u trajnoj napetosti između onoga što je „ovdje i sada“ i što bi trebao postati, odnosno na što je pozvan - biti u osobnom odnosu sa živim Bogom i biti njegova slika u svijetu. Čovjek je izložen neizvjesnosti, nesigurnosti koja dolazi iz borbe starog i novog Adama: ${ }^{34}$ stari Adam simbolizira čovjeka koji traži ovozemaljske gratifikacije, priznanja, i novog Adama, koji je otkupljen po visokoj cijeni i koji ima uzor u osobi Isusa Krista. Novi Adam nadilazeći ograničenja svoje prirode (usp. Kol 3,2-12) ima nov poziv, poslanje, misiju, naviještanje kerigme. ${ }^{35}$ Novi poziv je i nova cijena, ali i nova nagrada, vječni život.

Analizirajući iz psihološko-duhovne perspektive, čovjekov razvojni put između onog što je i onoga što još nije, a trebao bi postati, čini ga ranjivim. Paradoks je u tome da je ranjivost ta koja pomaže da se razumije ljudska krhkost da se spozna kako je ona pravo mjesto spasenja, mjesto ulaska Božje prisutnosti u čovjekov život. ${ }^{36}$ Ako se ranjivost definira kao nutarnju „golost“ pred Bogom, drugima, može se razumjeti da je ona pravo „mjesto“ susreta staroga i novog čovjeka: stari Adam, koji bježi, i novi Adam, koji se hrabro i odvažno hvata u koštac sa životom.

Na liniji biblijske parabole farizeja i carinika ${ }^{37}$ ranjivost se može priznati kao što to čini carinik, ili poricati, racionalizirati i spiritualizirati poput farizeja. U ovom prikazu može se iščitati moderna „pandemijska parabola“, u kojoj se može naći svaki kršćanin: u liku farizeja koji se ranjiv i ranjen potresom i pandemijom suočava sa svojom nutrinom, dotiče svoje strahove, sumnje, tugu, bol, depresiju, neizvjesnost, te stojeći pred Bogom otvara se Božjem djelovanju, zaziva ga i surađuje. U konačnici vjeruje u Božju providnost i, ne umanjujući psihološke datosti (ugodne i neugodne osjećaje), ne

33 Detaljan prikaz o utjecaju nezrelih i nesvjesnih dinamika na život kršćanina vidi: Luigi M. Rulla, Antropologija kršćanskog poziva 1, Kršćanska sadašnjost, Zagreb, 2001.

34 Usp. Porfirije Perić - Dragan Radić, Dijalektika „prvoga Adama“ i „posljednjega Adama“ u antropologiji apostola Pavla, Bogoslovska smotra 85 (2015.) 4, $1007-1025$.

35 Usp. Drago Tukara, Važnost prve kerigme za Crkvu i društvo danas, Bogoslouska smotra 90 (2020.) 3, 583-603.

36 „I reče mi: 'Dosta ti je milost moja, jer se sila u slabosti usavršava.' Rado ću se dakle hvaliti svojim slabostima, da se nastani u meni sila Kristova. Zato su mi ugodne slabosti, pogrde, nevolje, progonstva, tjeskobe zbog Krista, jer kad sam slab, onda sam jak“ (2 Kor 12, 9-10).

37 Usp. Mario Cifrak, Slika o Bogu ili etika (Lk 18,9-14)!?, Bogoslouska smotra 75 (2005.) 2, 541-555. 
da se zarobiti od njih nego ima potpuno predanje i vjeru da je Bog začetnik života i da ima konačnu riječ nad zemaljskim završetkom. I u ovo neizvjesno doba pandemije u onih koji Boga ljube, Bog sve okreće na dobro (usp. Rim 8,28). Ili suprotno, poput farizeja koji bježi u svoje obrane, mnoge kompenzacije kako bi izbjegao susret s vlastitim nutrinom. Bijeg od sebe bijeg je od promjene, bijeg od susreta koji bi mogao pozvati na napuštanje starih „ugoda“.

Socijalna izolacija otvorila je put samoći, vlastitoj ranjivosti, pogled u vlastitu otvorenost ili zatvorenost, uvid u vlastiti emocionalni svijet. Osobe koje su zbog COVID-a 19 bile u izolaciji, najčešće su u razgovorima, psihoterapiji i psihološkim konzultacijama verbalizirali sljedeća emocionalna stanja: ${ }^{38}$ strah, tjeskoba, nemir, frustracija, neizvjesnost, krivnja, sram, tuga, ljutnja, agresija, razočaranost. S druge pak strane, kada se govori o Bogu, neki su doživljavali pandemiju kao Božju kaznu, napuštenost od strane Boga, sumnju u Božju opstojnost i pravednost, sumnju u vječni život.

Za vjernika su patnja, izloženost, bolna iskustva potencijal za rast, prilika za pomicanje nutarnjih granica, otkrivanje novog horizonta. „Patnja može biti milosna prilika za istinsko i dubinsko obraćenje. “" ${ }^{99}$ Iskustvo žive vjere unatoč psihološkim turbulencijama može aktivirati vjeru, nadu i ljubav. Vjera koja u samoći daje odgovor da čovjek nije sam, obraća se nekome (kao što Isus razgovara s Ocem), nada povjerava Providnosti trenutnu bol (vjera je ufanje) i ljubav - iskrena ljubav koja se nesebično daruje, u trenucima vlastite boli misli na boli drugih, moli za sebe i za druge.

\section{PSIHOLOŠKA OTPORNOST}

Iz prethodnih studija i analiza provedenih u vrijeme intenzivnih valova pandemije vidljiv je progres psiholoških poteškoća i psihopatološka oboljenja, te razna tjelesna oboljenja - kardiovaskularnog, probavnog, endokrinog i drugog sustava - koji imaju psihogenu etiologiju. Ranjivost i ranjenost kod nekih su osoba značajno izražene, a kod nekih je i dalje u tijeku latentni proces koji postupno alterira fiziološku, psihološku i/ili duhovnu strukturu, tako da se manifestiranje simptoma i/ili bolesti mogu očekivati za nekoliko mjeseci, ili godina, kada već bude postpandemijska situacija.

38 Autor donosi sintezu iskustva psihoterapijskog rada u vrijeme pandemije COVID-a 19.

39 Dr. Marijan Vugdelija, Patnja i bol..., 424. 
Razlog zašto se netko uspijeva nositi s intenzivnim stresom, krizama, traumatskim iskustvima, leži u njegovoj psihološkoj otpornosti - rezilijentnosti - koja predstavlja ljudsku sposobnost prilagodbe pri suočavanju s različitim većim ili manjim poteškoćama, tragedijama, traumama, nedaćama i signifikantnim stresorima koji mogu varirati od osobnih do profesionalnih. ${ }^{40}$ Otpornost ne uključuje bilo kakav odgovor psihe i duha na izvanredne prilike, nego pozitivnu prilagodbu, prihvaćanje aktualne situacije te jačanje intrapsihičkih i interpersonalnih resursa, što uključuje reorganizaciju dosadašnjeg djelovanja, života. Pri toj prilagodbi dolazi do očuvanja mentalnog zdravlja usprkos teškoj situaciji. Otpornost kao dinamički proces važna je u razumijevanju „salutogeneze i patogeneze“. ${ }^{41}$ Otpornost na traumatski događaj može se definirati kao zdrav način funkcioniranja nakon izloženosti prijetnji. ${ }^{42}$

Otpornost može imati zaštitničku, ali i transformirajuću ulogu. Budući da ukazuje na elastičnost i prilagodljivost osobe koja se razvija od ranog djetinjstva i interakcije sa značajnim drugim/Drugim, otpornost se ne može smatrati urođenom, ni kao stanje ni kao karakterna osobina ili crta ličnosti. Ona se razvija kroz sve životne stadije, koji obuhvaćaju čitavu ontogenezu, od rođenja do kraja života. Formaciju otpornosti može se, prema Eriksonu, promatrati tijekom 8 razvojnih stadija u kojima se pozitivno ili negativno rješavaju razvojne poteškoće. Otpornost se „gradi“ suočavanjem s izazovima i zadacima u svakom stadiju, te nadvladavanjem razvojne dijalektike. U ranom razvojnom razdoblju razvoj otpornosti potiču funkcionalni obiteljski odnosi, emocionalna podrška, topao i brižan odnos roditelja prema djetetu. Drugim riječima, okolina u kojoj osoba živi, psihološki i socijalni odnosi, te intrapsihička struktura utječu na razvoj otpornosti. Iako su važni biološki i genetski čimbenici, otpornost se ipak razvija u relacijskom kontekstu, u odnosu sa drugim/Drugim.

40 Usp. Romana Babić - Mario Babić - Pejana Rastović, Resilience in health and illness, Psychiatria Danubina 32 (2020.) 2, 226-232; Newman, R. (2005). APA's resilience initiative, Professional psychology: Research and practice, 36 (2005.) 3, 227-229.

41 Miro Jakovljević, Resilience, psychiatry and religion from public and global mental health perspective Dialogue and Cooperation in the Search for Humanistic Self, Compassionate Society and Empathic Civilization, Psychiatria Danubina 29 (2017.) 3, 239.

42 Usp. Steven M. Southwick - George A. Bonanno - Ann S. Masten, Resilience definitions, theory, and challenges: interdisciplinary perspectives, European Journal of Psychotraumatology, 5 (2014.) https://doi.org/ 10.3402/ejpt.v5.25338 (23. 4. 2021.). 
Kada se promatra transformirajuća snaga otpornosti, onda se može zaključiti da ona osigurava ne samo preživljavanje nego potiče bolji rast i napredovanje bilo pojedinca bilo zajednice. Postoje pojedinci koji su nakon posttraumatskog iskustva proširili svoje psihološke kapacitete, sazreli na naravnoj i nadnaravnoj razini. Rezilijentnije osobe pod manjim su rizikom od razvoja mentalnih i tjelesnih poremećaja, imaju bolji imunološki odgovor, kraće im traje oporavak nakon bolesti. Kod otpornih osoba resursi su otvoreni za veću kreativnost i produktivnost.

Budući da otpornost uključuje dvije razine, intrapsihičku (odnos prema vlastitim mislima, osjećajima, ponašanju) i interpersonalnu (odnos prema drugima), ona se raznim intervencijama, metodama, edukacijama može jačati kako u odnosu prema sebi tako i prema drugima. U kliničkim ustanovama koje skrbe o mentalnom zdravlju osoba, raznim preventivnim i psihoterapijskim programima može doći do značajnog poboljšanja kvalitete života, što utječe na povećanje otpornosti, kako na intrapsihičkoj tako i na interpersonalnoj razini. Prema nedavnom kliničkom istraživanju potvrđeno je da je primjenom raznih oblika intervencija - psihološke, farmakološke i bihevioralne metode - došlo do poboljšanja psihičkog zdravlja, fizičkog zdravlja, percepcija utjecaja okoline te socijalnih odnosa. ${ }^{43}$

\section{STRATEGIJE ZA JAČANJE PSIHOLOŠKE I DUHOVNE OTPORNOSTI}

Za osobe koje su sklone ne voditi brigu o mentalnoj higijeni, koja, između ostalog, uključuje poznavanje vlastite nutrine, nagona, emocija, psiholoških potreba, te proradu posebno bolnih i neugodnih afektivnih stanja, razvoj i jačanje mentalnih struktura, može izgledati kao kozmetički trend. No, takva su uvjerenja pogrešna i pogoršavaju psihološku napetost, koja, s druge strane, pronalazi ispusni ventil u toksičnim izborima i hiperkonzumaciji cigareta, alkohola, hrane, pornografije i drugih oblika kompenzatorskih gratifikacija. Stoga, kako bi se ojačala psihološka struktura u vrijeme trajanja zarazne epidemije, neophodno je napraviti nove okvire, strategije za mentalnu higijenu, baviti se vlastitom nutrinom, promatrati što osobu uznemiruje, što je plaši, razgovarati s bližnjima o tome, ili sa stručnjakom, učiti nove oblike izražavanja nezadovoljstva, frustracije, straha. Na temelju psihoterapijskog iskustva u vri-

43 Usp. S. Topić Lukačević - Slobodanka Cvitanušić - Igor Filipčić, Poticanje rezilijencije, a time i kvalitete života kod stresom i traumom uzrokovanih poremećaja putem kriznih intervencija, Socijalna psihijatrija 48 (2020.) 3, 257-284. 
jeme COVID-a 19 pokazalo se da je od svih emocija tugu bilo najteže prepoznati, prihvatiti i proraditi. Uz stručnu pomoć, socijalna potpora i emocionalna blizina drugih osoba od presudne su važnosti za održavanje i jačanje otpornosti.

Čovjek može utjecati na pojavu i razvoj stresa koristeći se raznim metodama koje pomažu u relaksaciji, npr. duboko disanje, čitanje zanimljive literature, slušanje opuštajuće glazbe, redovita tjelovježba, humor, uravnotežena prehrana, aktiviranje starih, tradicionalnih djelatnosti poput rada vlastitim rukama. Osobe koje nemaju razvijene sublimatorne kanale, drugim riječima hobije, koriste vlastito tijelo da kanaliziraju frustraciju i nezadovoljstvo, što se pokazuje u mnogim oblicima autoagresije.

Postoje mnoga istraživanja koja ukazuju kako aktivan duhovni život pridonosi jačanju otpornosti. ${ }^{44}$ Kod vjernika vrlo važnu ulogu ima duhovna dimenzija, odnosno povezanost s Bogom u molitvi, meditaciji, svakodnevnom razgovoru s Njim. Duhovni život koji se hrani Božjom riječju i djelima služenja u obitelji i zajednici, jača i psihološku strukturu i hrani nadu i pouzdanje u teškim trenucima. Jačajući duhovnu otpornost kroz molitveni život, čovjek jača svoju psihološku strukturu i postaje sposoban za stvarno dobro i nesebičnu ljubav. Prema istraživanju Rossettija osobna molitva u trajanju od pola sata do sat vremena $u$ izravnoj je korelaciji s poboljšanjem psihičkog i duhovnog zdravlja. ${ }^{45}$ Razne studije potvrđuju da zdrava duhovnost i sadržajno bogat duhovni život jačaju otpornost psihe i duha na mnoge štetne utjecaje, ${ }^{46}$ a povjerenje u Božju ljubav i providnost osposobljava osobu da pronađe smisao u svemu što joj se događa te da zauzme aktivan stav duha i psihe, a ne pasivan, koji vodi u bespomoćnost i bezizlaznost.

\section{ZAKLJUČAK}

U 21. stoljeću pojava pandemije COVID-a 19 pokazala je svu krhkost čovjeka, nestabilnost njegovih interpersonalnih odnosa

44 Usp. Miro Jakovljević, Resilience, psychiatry and religion from public and global mental health perspective Dialogue and Cooperation in the Search for Humanistic Self, Compassionate Society and Empathic Civilization, Psychiatria Danubina 29, (2017.) 3, 239.

45 Usp. Stephen J. Rosseti, Why priests are happy. A study of the psychological and spiritual health of priests, Ave Maria Press, Notre Dame, Indiana, 2011., 175-176.

46 Usp. Lindsay Smith - Ruth Webber - John DeFrain, Spiritual Well-Being and Its Relationship to Resilience in Young People: A Mixed Methods Case Study, Sage Open (2013.) 1-16, https://doi.org/10.1177/2158244013485582 (14. 5. 2021.). 
na mikrorazini i makrorazini. Stresne situacije u kojima se čovjek našao uzrokovale su da je na površinu izašao jedan dublji strah koji ima korijene $u$ razdoblju prije nego što se pojavio masovni strah od COVID-a 19 nazvan koronafobija. Taj duboki strah strah je od susreta sa samim sobom i svojom nutrinom, strah od susreta s Bogom koji poziva na predanje i suradnju, strah od gubitka privilegija i statusa, strah od bolesti, strah od nestajanja, u konačnici strah od smrti. Postmoderni čovjek od završetka „ratova“ nije bio izloženiji većem stresu i dramatičnijim situacijama nego što je to u vrijeme lockdowna, crnih lista preminulih i sl. Takva stanja omogućila su da na površinu ispliva tko je uistinu čovjek i što nosi u sebi?!

Kultura tijela, estetike, mentalne higijene koja teži da čovjeka oslobodi od svih strahova i da ga učini gospodarom koji može kontrolirati sebe i druge kapitulirala je preko noći. Čovjek se iznenada susreo s mogućnošću gubitka egzistencije, vlastitog života, života bližnjih, što je rezultiralo pojavom neizvjesnosti i difuzijom tjeskobe. Izgubio je mnoge alate kojima se branio i stvarao materijalni „imperij“. Pandemija je čovjeka usmjerila na njega samoga i na druge, pokazala je kakav je: (ne)solidaran, (ne)odgovoran, (ne) empatičan, tjeskoban, agresivan, depresivan, uplašen. Ranjivost i ranjenost pred kojom se našao, emocionalno ga je blokirala, što se pokazalo kroz mnoge oblike psihosomatskih obljenja, nasilja u obitelji, nasilja nad sobom i drugima.

Iz ovoga slijedi da je psihološka i duhovna otpornost čovjeka u postmoderni slabo razvijena i da zahtijeva nove strategije za jačanje i unaprjeđenje. Ranjivost je veća što je slabija otpornost, drugim riječima, manjak otpornosti i kolaps zdravih obrana dovodi do toga da od ranjivosti čovjek postane ranjen. Stoga je briga za vlastitu ranjivost u 21. stoljeću - stoljeću raznih prijetećih pandemija - te jačanje psihološke i duhovne otpornosti imperativ, a ne jedna od mogućih opcija za unaprjeđenje mentalnog zdravlja. Ako se nastavi sustavno zanemarivati pitanje mentalnog i duhovnog zdravlja u vrijeme pandemije, a nastave mjere kojima je prvotni cilj osigurati fizičko zdravlje, broj mentalnih oboljenja bit će puno veći, a psihičke poteškoće puno teže. U doba pandemije zdravstveni i politički sustavi trebaju razvijati programe koji će integrirati i promicati zdravlje na sve tri razine čovjekova života, a ne slijediti politiku redukcionizma. 


\section{CARING FOR OUR VULNERABILITY AND RESILIENCE DURING THE COVID-19 PANDEMIC}

\section{Summary}

The time of the Covid-19 pandemic can be described as a time of unexpected, intense stress due to which human vulnerability and psychological (in)resilience emerged at the top of the iceberg. Prolonged uncertainty, insufficient knowledge of the course, mutations and consequences of the disease combined with emotional, social, spiritual and economic constraints have affected the person's sense of self and the environment, as well as the perception of living in a time of stable instability.

Starting from Christian anthropology, the purpose of the paper is to sensibilize and actualize the care of one's own vulnerability and resilience, especially in the postmodern era when man predominantly cares for the cult and aesthetics of the body, and the interiority remains neglected. The appearance of various pandemics and phobias - the pandemic of mental disorders, the phenomenon of coronaphobia - the mass fear of Covid-19, are just some of the significant signs that should be imperatively read as a call to return to oneself and strengthen intrapsychic and interpersonal capacities.

In addition to analyzing and diagnosing the mental state at the time of Covid-19, the purpose of this paper is to explore the sources of vulnerability from the psychological and spiritual dimension in order to indicate the path how to accept and integrate one's own vulnerability and strengthen psychological and spiritual resilience.

The paper is divided into 4 parts: the first part analyzes the situation during the coronavirus pandemic, the second part explores the dynamics of vulnerability from the psychological-spiritual dimension, the third part deals with resilience, and the final part provides guidelines for strengthening psychological and spiritual resilience.

Key words: Covid-19 pandemic, stress, vulnerability, resilience, integration 